6

17

Anthropogenic disturbance of deep-sea megabenthic assemblages: a study with Remotely-Operated Vehicles in the Faroe-Shetland Chanel, NE Atlantic

\author{
Jones, D. O. B. ${ }^{1}$, Wigham, B. D. ${ }^{2}$, Hudson, I. R. ${ }^{1}$ and Bett, B. J. ${ }^{1}$
}

1 DEEPSEAS Group, George Deacon Division, National Oceanography Centre, Southampton. SO14 3ZH. UK.

2 Dove Marine Laboratory, School of Marine Science and Technology, Newcastle University, Cullercoats. NE30 4PZ. UK.

10

Corresponding Author:

2 Daniel O. B. Jones

e-mail: dj1@noc.soton.ac.uk

4 tel: +44 (0) 2380596357

fax: +44 (0) 2380596247 
3 The effects of local-scale anthropogenic disturbance from active drilling platforms on

4 epibenthic megafaunal abundance, diversity and assemblage pattern were examined in

5 two West of Shetland hydrocarbon fields at $420 \mathrm{~m}$ and $508 \mathrm{~m}$ water depth. These

6 areas were selected to include a range of disturbance regimes and contrasting faunal

7 assemblages associated with different temperature regimes. Remotely Operated

8 Vehicle (ROV) video provided high-resolution megafaunal abundance and diversity

9 data, which were related to the extent of visible disturbance from drilling spoil. These

10 data, in conjunction with a study deeper in the Faroe-Shetland Channel, have allowed

11 comparison of the effects of disturbance on megabenthos across a range of sites.

12 Disturbance to megafaunal assemblages was found to be high within $50 \mathrm{~m}$ of the

13 source of drill spoil and in areas where spoil was clearly visible on the seabed, with

14 depressed abundances (Foinaven 1900 individuals ha ${ }^{-1}$; Schiehallion 2178 individuals

$\left.15 \mathrm{ha}^{-1}\right)$ and diversity $\left(\mathrm{H}^{\prime}=1.75\right.$ Foinaven; 1.12 Schiehallion) as a result of smothering

16 effects. These effects extended to around $100 \mathrm{~m}$ from the source of disturbance,

17 although this was variable, particularly with current regime and nature of drilling

18 activity. Further from the source of disturbance, megafaunal assemblages became

19 more typical of the background area with increased diversity $\left(\mathrm{H}^{\prime}=2.02\right.$ Foinaven;

201.77 Schiehallion) and abundance (Foinaven 16484 individuals ha ${ }^{-1}$; Schiehallion

215477 individuals $\mathrm{ha}^{-1}$ ). Visible effects on megafaunal assemblages as a result of

22 seabed drilling were limited in extent although assemblage responses were complex,

23 being controlled by differing effects to individual species often based on their

24 motility. 
Disturbance is an important source of temporal and spatial heterogeneity in

4 natural communities (e.g. Sousa 1984). The importance of disturbance has been

5 highlighted (e.g. Connell 1978) in maintaining species diversity by preventing

6 competitive exclusion by dominant species in an assemblage. Physical disturbance is

7 a key factor in controlling spatial and temporal composition of shallow-water benthic

8 communities. Like shallow waters, deeper waters are now increasingly subject to a

9 range of anthropogenic perturbations that include commercial trawling (Kaiser 1998),

10 mining (Radziejewska and Stoyanova 2000) and increasingly oil exploration (Jones et

11 al. 2006). Oil exploration activities are becoming more important in the Faroe-

12 Shetland Channel with the majority of fields located on the upper slope (Figure 1).

13 This area supports a high diversity of deep-water fauna primarily controlled by its

14 unusual temperature regime (Turrell et al. 1999; Bett 2001). This study will compare

15 the effects of disturbance from drilling on megafaunal assemblages in the three major

16 thermal regimes encountered in the Faroe-Shetland Channel between 200 and $1000 \mathrm{~m}$

17 water depth. This study extends that of Jones et al. (2006) to include new megafaunal

18 data from contrasting thermal regimes.

19 Human induced disturbance in the deep sea typically has a large impact on

20 benthic communities (Bluhm 2001). Deep-sea environments are typically stable in

21 comparison with often more dynamic shallow-water habitats (Gage and Tyler 1991).

22 Physical habitat characteristics are important in controlling benthic community

23 structure (Levin et al. 2001). Anthropogenic disturbance from a variety of sources can

24 alter these characteristics very rapidly by smothering the existing seabed with

25 sediments from elsewhere (Stronkhorst et al. 2003; Jones et al. 2006). In addition, 
1 large-scale disturbance can also occur naturally in deeper waters from turbidity

2 currents, debris flows and benthic storms (Gage and Tyler 1991). In communities with

3 limited food supply and with invertebrate assemblages depauperate in both abundance

4 and biomass, disturbance effects are likely to be greater and recovery times longer

5 (Bluhm 2001). The greatest change in communities may be expected to occur in areas

6 where disturbance alters habitat type most radically. The upper slope of the Faroe-

7 Shetland Channel harbours an unusual deep-sea habitat consisting of a heterogeneous

8 mix of sediments with a preponderance of hard substratum (cobble, boulder).

9 Introduction of drill spoil acts to reduce hard substratum availability and homogenise

10 the habitat, which can directly influence the abundance, diversity, species composition

11 and distribution of the local benthic fauna (Jones et al. 2006).

12 The effects of anthropogenic disturbance, such as oil drilling activity, on the

13 benthic environment is conventionally assessed by sampling (typically by grab) a

14 range of chemical parameters and occasionally macrofauna from the source of effect

15 at geometrically increasing distances along four radiating transects (Gray et al. 1990;

16 Kingston 1992). The effects on macrofauna are usually recorded as changes in

17 diversity indices (Davies et al. 1989; Kingston 1992), although multivariate

18 approaches may be more effective (Olsgard and Gray 1995). The effects of physical

19 disturbance on whole assemblages is less well known, with shallow-water studies

20 suggesting a range of responses depending on the severity of disturbance and nature

21 of the assemblage (Airoldi 2003; Dernie et al. 2003).

22 Typical environmental assessments do not specifically address the larger

23 epibenthic megafauna, yet these organisms play an important role in benthic processes

24 (Piepenburg and Schmid 1997). Monitoring of megafauna has been shown to be

25 effective in evaluating the impacts of disturbance on the seafloor (Bluhm 2001). 
1 Photographic studies allow fine scale survey of megabenthic abundance, diversity and

2 distribution (Piepenburg and Schmid 1997) and can have a much larger spatial extent

3 than is usually possible with conventional macrofaunal sampling techniques.

4 Remotely Operated Vehicles (ROV) are ideal tools for such surveys, capable of high

5 resolution, systematic video and photographic investigation of epibenthic megafaunal

6 assemblages (e.g. Jones et al. 2006).

7 The main objectives of this study are to: 1) describe the composition, diversity

8 and distribution of megafaunal assemblages on the Faroe-Shetland Channel slope, 2)

9 determine the effect and extent of physical disturbance from drilling operations on

10 benthic megafauna, 3) determine the differences between benthic megafaunal

11 assemblages and their responses to disturbance at two contrasting study sites and 4)

12 compare results from these with existing data collected in an identical manner at a

13 deeper Faroe-Shetland Channel site (Jones et al. 2006).

14

15 MATERIALS AND METHODS

16

17 Study background:

18 Investigations for this study were carried out aboard the semi-submersible oil 19 drilling platforms Paul B Loyd Junior (PBLJ, 14-28/5/2003) and Transocean Leader 20 (TOL, 27/9-3/10/2003). The PBLJ was operating in the Foinaven field (507-509 m 21 depth, $60^{\circ} 18.68^{\prime} \mathrm{N} 4^{\circ} 20.33^{\prime} \mathrm{W}$ ) and TOL in the Schiehallion field (420-421 m depth, $\left.2260^{\circ} 22.95^{\prime} \mathrm{N} 04^{\circ} 05.95^{\prime} \mathrm{W}\right)$. The Foinaven and Schiehallion oil reservoirs were 23 discovered in 1992 and 1993 respectively. Drilling activities began in the Foinaven 24 region in 1997 and in the Schiehallion region in 1998. 
Drill spoil was deposited on the seabed during the initial phases of drilling

2 (tophole drilling) as sediment is displaced directly. Once this phase is completed all

3 subsequent rock cuttings were recirculated with drilling mud back to the rig where

4 they were cleaned and depending on potential contamination, discharged at the

5 surface or shipped back to land. With the high current regime in the Faroe-Shetland

6 Channel the rock cuttings disposed at the surface were spread widely and very little

7 was deposited on the seabed close to the rig (Aurora 2004). In this environment, the

8 majority of spoil deposited on the seabed close to the drill site was produced for less

9 than a day per well during tophole drilling. In the area investigated at Foinaven, 14

10 wells were present at the time of investigation within $50 \mathrm{~m}$ of each other. These wells

11 had been drilled over a 5 year period with the most recent still being drilled during

12 this investigation. Seabed spoil resulting from this drilling operation was produced 14

13 days prior to the start of the investigation (1/5/2003), over a period of approximately

1424 hours. In the area investigated at Schiehallion there was only one well, which was

15 also being drilled during this investigation. Seabed disturbance from tophole drilling

16 occurred twice owing to operational problems, 12 and 14 days before this

17 investigation began (on 13 and 15/9/2003; both for approximately 24 hours).

18 For survey purposes the seabed around the drilling activity was divided into 50

$19 \mathrm{~m}$ zones radiating from the outer limit of all seabed installations (Figure 2). The area

20 to the southeast of the Foinaven well could not be surveyed owing to operational

21 constraints. The distance of the ROV from the rig was calculated from transect

22 duration and the length of the ROV tether released from the Tether Management

23 System with an approximate error of $\pm 1 \mathrm{~m}$. Data were collected using an industry-

24 operated work-class Pioneer HD ROV, following the methodology of Jones et al.

25 (2006). 


\section{Data analysis}

3

4 Abundances were standardised to numbers per hectare. Each transect was

5 partitioned into $50 \mathrm{~m}$ zones and analysis was carried out on data from each zone.

6 There were 5 zones at Foinaven $(0-250 \mathrm{~m})$ and 4 at Schiehallion $(0-200 \mathrm{~m}$, owing

7 to limited data in the $250 \mathrm{~m}$ zone at Schiehallion). Counts for each individual transect

$850 \mathrm{~m}$ zone formed the sampling unit.

9 A range of univariate diversity indices were calculated to assess both the

10 dominance and species richness aspects of diversity (Magurran 2003). Confidence

11 intervals (95\%) for abundance and diversity were calculated using a bootstrapping

12 technique (Manly 1998). As implemented here, 1000 bootstrap samples were

13 calculated and a 95\% confidence interval determined from the resultant data.

14 Variations in taxon composition were assessed by multivariate analysis 15 (hierarchical group-average clustering and non-metric multi-dimensional scaling, 16 MDS) following a square root transformation and calculation of Bray-Curtis 17 similarity coefficients (Clarke and Warwick 2001). The difference in assemblage 18 composition between distance zones was assessed using analysis of similarities 19 (ANOSIM). Multivariate dispersion (MVDISP) was used to measure within-zone 20 multivariate assemblage dispersion (Clarke \& Warwick 2001). Data analysis was 21 performed using the computer programmes PRIMER (Clarke and Warwick 2001), 22 Biodiversity Pro (Natural History Museum, London and Scottish Association for 23 Marine Sciences, Oban), MATLAB (MathWorks Inc.) and MINITAB (Minitab Inc.). 


\section{RESULTS}

\section{(1)}

\section{Foinaven}

\section{General observations}

At Foinaven 1075 megabenthic organisms from 33 nominal taxa were recorded in a total area of $1519 \mathrm{~m}^{2}$ (Table 1; Figure 3 \& 4). Crustaceans were the dominant megafaunal group (47\% megafauna; $5253 \mathrm{ha}^{-1}$ ), predominantly represented by the ubiquitous squat lobster Munida sarsii, but also included hermit crabs, natant decapods and Siphonocetes tube dwelling amphipods. Porifera (27\% megafauna, 3382 ha $^{-1}$ ) were abundant. Echinoderms (22\% megafauna, 2046 ha $^{-1}$ ) were dominated by Echinus acutus and the holothurian Stichopus tremulus. Asteroids (Porania pulvillus pulvillus, Ceramaster granularis and Henricia pertusa), comatulid crinoids and ophiuroids were also present. The remainder (4\%) of the megabenthos was made up of molluscs, polychaetes, cnidarians and demersal fish. Seabed structures at Foinaven attracted large numbers of fish (predominantly Sebastes viviparus, Brosme brosme and Pollachius virens) but in disturbed areas benthic megafauna were relatively sparse, being largely represented by motile deposit feeders principally echinothurid urchins and Munida sarsii.

Despite the large number of drilling sites in the Foinaven study area, drill spoil was constrained to a $\sim 50 \mathrm{~m}$ zone around the drill sites. Outside the disturbed area the seabed consisted of a heterogeneous mix of sand, gravel and occasionally larger cobbles and boulders characteristic of the “iceberg ploughmark zone” (Bett 2001; Masson 2001). 
2

\section{Abundance}

Megafaunal abundance (Figure 3A) was significantly different between zones (Kruskal-Wallis $\mathrm{H}=22.81$, $\mathrm{df}=4$, $\mathrm{p}<0.001$ ) increasing with distance from drilling activity at Foinaven (Spearman's rank correlation $r^{\prime}=0.9, p<0.05$ ). Large changes in abundance with distance from disturbance were observed particularly for dominant phyla, with Porifera and Crustacea displaying changes in abundance by almost an order of magnitude. A marked increase in abundance between 0 and $100 \mathrm{~m}$ from drilling activity was noted for major faunal groups with post-hoc non-parametric multiple comparisons of total faunal abundance (after Miller 1981) revealing significant differences $(\mathrm{p}<0.05)$ between the $0-50 \mathrm{~m}$ zone and all other zones, but no significant differences between zones $>50 \mathrm{~m}$ from the drilling disturbance. Both motile and sessile taxa abundances were significantly different between zones (Kruskal-Wallis: motile: $\mathrm{H}=20.80$, $\mathrm{df}=4, \mathrm{p}<0.001$; sessile: $\mathrm{H}=23.87$, $\mathrm{df}=4, \mathrm{p}<$ 0.05). Sessile taxa increased continuously in abundance from very low values close to the source of disturbance. Motile taxa had low abundances close to disturbance but increased beyond $50 \mathrm{~m}$. Beyond $50 \mathrm{~m}$ from the source of disturbance there was no significant differences in motile megafaunal abundance ( $p>0.5$ in post-hoc nonparametric multiple comparisons).

\section{Diversity}

Univariate diversity measures (Figure 4A) revealed significant changes in diversity with distance from the disturbance. Species richness was lowest close to the source of disturbance, increased to peak values at intermediate distances and dropped slightly in the least disturbed 250 m zone. Heterogeneity diversity $\left(\mathrm{H}^{\prime}\right)$ changed 
1 significantly between zones (Kruskal-Wallis $\mathrm{H}=22.31$, $\mathrm{df}=4, \mathrm{p}<0.001$ ), revealing

2 lowest diversity in the area of drill spoil disturbance, particularly that within

3 structures. This was primarily driven by lack of rarer species, revealed in type I

4 indices (those that emphasis the rarer component of the assemblage). Heterogeneity

5 diversity followed similar trends to species richness, increasing at intermediate

6 distances and dropping slightly further away.

7

8 Composition

9

\section{Schiehallion}

\section{General observations}

At the Schiehallion site a total of 1133 megabenthic organisms from 17 nominal taxa were recorded from a total area of $2715 \mathrm{~m}^{2}$ (Table 1). Porifera were the 
1 dominant group (62\% megafauna, $2819 \mathrm{ha}^{-1}$ ) followed by Echinodermata (26\%

2 megafauna, $1170 \mathrm{ha}^{-1}$ ) which were dominated by Cidaris cidaris urchins, the

3 holothurian Stichopus tremulus and various asteroids (Porania pulvillus pulvillus,

4 Ceramaster granularis, Asterias rubens and Henricia pertusa). Crustaceans (11\%

5 total megafauna, 495 ha $^{-1}$ ) were predominantly represented by Munida sarsii but also

6 included hermit crabs, Geryon sp. and Cancer pagarus. The remainder (1\%) of the

7 megabenthos comprised molluscs and polychaetes. In the area of drill spoil fish were

8 present (predominantly Gadus morhua, Helicolenus dactylopterus dactylopterus and

9 Molva molva), and were most abundant around drilling structures although in lesser

10 numbers than at Foinaven.

11 At Schiehallion, despite there being only one drill site, the extent of spoil was

12 greater than at Foinaven, extending to over $155 \mathrm{~m}$ in places. Outside the disturbed 13 area the seabed consisted of a heterogeneous mix of sand, gravel and occasionally 14 larger cobbles and boulders.

15

16 Abundance

17

Large changes in abundance with distance from drilling activity were observed, particularly for dominant phyla. Megafaunal abundance (Figure 3B) was significantly different between zones (Kruskal-Wallis $\mathrm{H}=15.45$, $\mathrm{df}=3$, $\mathrm{p}<0.001$ ); increasing with distance from drilling activity $\left(r^{\prime}=0.982, p<0.001\right)$. A large increase in abundance between 0-50 and 50-100 m from drilling activity was noted for major faunal groups with post-hoc non-parametric multiple comparisons of total faunal abundance (after Miller 1981) revealing significant differences $(\mathrm{p}<0.05)$ between the 0-50 m zone and all other zones but no significant differences between zones $>50 \mathrm{~m}$ from the drilling disturbance. Both motile and sessile taxa abundances were 
1 significantly different between zones (Kruskal-Wallis: motile: $\mathrm{H}=26.96, \mathrm{df}=3, \mathrm{p}<$

20.001 ; sessile: $\mathrm{H}=8.11$, $\mathrm{df}=3, \mathrm{p}<0.05$ ). Sessile taxa abundance increased

3 continuously with distance from disturbance while motile faunal abundances peaked

4 at intermediate distances before declining again between 150-200 m.

\section{Diversity}

7

Species richness was low close to the source of disturbance, increased to a maximum in the $150 \mathrm{~m}$ zone and dropped slightly in the zone furthest from disturbance (Figure 4B). Significant differences in heterogeneity diversity were observed between zones in $\mathrm{H}^{\prime}$ (Kruskal-Wallis $\mathrm{H}=17.63$, $\mathrm{df}=3, \mathrm{p}<0.001$; Figure 4B), owing to depressed megafaunal diversity in the $50 \mathrm{~m}$ zone (particularly in indices weighted towards rarer species). Outside this zone there was no significant difference in $\mathrm{H}^{\prime}$ (post-hoc non-parametric multiple comparisons $\mathrm{p}>0.05$ ).

\section{Composition}

Multivariate analyses (Figure 5\&6) showed significant differences in megafaunal assemblages with distance from disturbance $($ ANOSIM R $=0.26, \mathrm{p}<$ 0.05). The fauna in the $50 \mathrm{~m}$ zone were highly scattered in the MDS ordination (65.86\% similarity). While distinct from other stations, the $50 \mathrm{~m}$ zone samples had high within zone dispersion of samples (MVDISP $=1.24$ ). Beyond this transition zone diversity was high and distance from the source of drilling did not appreciably affect the assemblage, all of these outer zones formed a grouping on the MDS plot and showed high similarity with cluster analysis (> 85\%; Figure 5\&6). There was relatively low dispersion of within zone samples (mean MVDISP $=0.93$ ). 


\section{Comparison between sites}

3

4

\section{Changes in megabenthic assemblages with disturbance}

Total megafaunal abundance was higher in Foinaven except in the areas less than $50 \mathrm{~m}$ from the source of disturbance. Motile faunal abundance followed similar patterns at both sites but was typically around 4 times greater in Foinaven. Sessile faunal abundances were considerably lower close to disturbance in Foinaven but were approximately equal outside this area.

Megafaunal species richness and heterogeneity diversity were significantly lower at Schiehallion when compared to Foinaven (based on grand site totals: Schiehallion $\mathrm{S}=18, \mathrm{H}^{\prime}=1.66$; Foinaven $\mathrm{S}=33, \mathrm{H}^{\prime}=2.05$ ) despite the larger survey extent at Schiehallion. Notable differences in megabenthic assemblage composition were observed between Schiehallion and Foinaven (ANOSIM R = 1.00, p $<0.01$; Figure 6). Although 15 of the observed taxa were common to both areas, there were some notable differences in important taxa. For example Cidaris cidaris was the only echinoid observed at Schiehallion, however at Foinaven no cidarids were recorded and large numbers of Echinus acutus and other Echinus sp. urchins dominated instead. There were also differences amongst megafaunal scavengers: at Schiehallion crabs appeared to be predominant (particularly Geryon sp.), whereas at Foinaven these were not present and natant decapods and whelks were more common.

\section{DISCUSSION}


The extent of disturbance was shown to drive changes in megafaunal

2 abundance; low megafaunal numbers were associated with drill spoil and close to

3 sites of recent drilling impact. Physical smothering and burial of organisms was likely

4 to be the most important cause for reduction in megafaunal numbers (Stronkhorst et

5 al. 2003). Highly motile organisms responded by moving away from the disturbance,

6 as has been found in other studies (e.g. Bluhm 2001; Jones et al. 2006). For less

7 motile taxa, reduced motility led to increased mortality. Where disturbance was

8 partial, the megafaunal response to disturbance in this study was based not only on

9 motility but also on feeding mode, particle removal rate and degree of disturbance.

10 Sessile megafauna increased in abundance with a reduction in disturbance.

11 Impact of drilling disturbance on sessile forms was related directly to their ability to

12 clear particles from their feeding and respiratory surfaces as shown in many sessile

13 shallow-water organisms (Rogers 1990). Sessile megafauna were less disturbed at

14 Schiehallion where abundance was significantly greater than Foinaven (particularly in

15 the area close to disturbance) as a result of reduced overall disturbance. At the deep-

16 water (600 m) Laggan site sessile fauna showed a similar response to Foinaven. The

17 Laggan site is also situated in the Faroe-Shetland Channel $\left(60^{\circ} 57^{\prime} \mathrm{N}, 02^{\circ} 53^{\prime} \mathrm{W}\right)$ in an

18 area with similar substratum but colder seabed temperatures ( -1 to $2^{\circ} \mathrm{C}$ ) than those

19 investigated here (Jones et al. 2006).

20 Megafaunal species diversity generally increased with distance from the point

21 of disturbance as reduced levels of sedimentation increased survival of sessile and

22 other less resilient organisms. Some diversity indices showed a small decrease in

23 diversity at maximal distance and minimal disturbance. Diversity was depressed by

24 high disturbance, but intermediate levels may have increased diversity levels through

25 influx of vagrant scavenging animals or motile fauna taking advantage of decreased 
1 competition as a result of reduced numbers of dominant species (Connell 1978) as

2 was also found to occur at Laggan (Jones et al. 2006). Multivariate measurements for

3 the whole assemblage revealed an increased similarity of megabenthic assemblages

4 with decreased disturbance. This trend has been commonly observed in community

5 measures in many marine disturbance settings (Clarke and Warwick 2001) and also

6 found at the Laggan site deeper in the Faroe-Shetland Channel (Jones et al. 2006).

$7 \quad$ Timing and extent of disturbance appears to have been an important factor in

8 this study with the least disturbed Schiehallion site having less discernable changes in

9 assemblage structure than the repeatedly disturbed Foinaven site. The Laggan site

10 (Jones et al. 2006) had two drilling events similar to Schiehallion but relatively higher

11 disturbance (greater coverage of drill spoil) and greater changes in assemblage

12 structure were observed. Frequent disturbance has been shown to have dramatic and

13 long lasting effects on shallow-water communities of the North Sea (Stronkhorst et al.

14 2003) and a similar effect would be expected in deeper water. It was apparent,

15 however, that there was some immigration of selected mobile megafaunal taxa into

16 disturbed zones, this also occurred at Laggan (Jones et al. 2006) and has been found in

17 studies of fishing disturbance (Ramsay et al. 1998). With disturbance from drilling

18 leading to reductions in suspension feeder abundance and an increase in availability of

19 fine particles of high organic matter content it is likely that deposit feeding forms such

20 as echinoids and holothurians may preferentially colonise drill spoil as individual

21 animals can select and retain fine particles without the need to sort through more

22 heterogeneous sediment complexes (Hudson et al. 2004). Although this study was

23 based on two distinct points in time the first phases of recovery were already apparent.

24 Physical disturbance observed at the study sites resulted in complete coverage

25 with sediment (presumed mortality) and potentially non-lethal effects from physical 
1 smothering. These effects have also been observed in studies on disposal grounds for

2 dredged material (Stronkhorst et al. 2003), however the associated chemical changes

3 were not investigated in this study. Increase in drilling derived particulates as a result

4 of disturbance may have lead to non-lethal effects such as clogging of filter feeding

5 apparatus of some organisms (Sharma et al. 2001). Although redistribution of nutrient

6 rich subsurface layers could lead to an increase in population size over time

7 (Raghukumar et al. 2001; Sharma et al. 2001), it is likely that the initial impacts of

8 changes in seabed habitat will have had the dominant effect on the benthic

9 communities.

10 The composition of seabed sediments changed as a result of drilling activity,

11 from a heterogeneous substratum with extensive exposed hard surfaces to a 12 homogeneous soft substratum. This change further reduced diversity and although 13 changes are difficult to separate from those directly related to disturbance, reduction 14 in habitat heterogeneity has been shown to reduce diversity in the deep sea (Levin et 15 al. 2001). Smothering of existing sediment with that of a different composition 16 resulted in conditions unfavourable to existing communities and would therefore 17 reduce rates of re-colonisation and larval settlement, potentially prolonging recovery 18 (Snelgrove et al. 1999). Changes in substratum may also have favoured particular 19 faunal elements in the existing communities, increasing dominance and altering 20 community composition.

21 Outside of the area impacted by drill spoil there was a highly heterogeneous 22 distribution of benthic megafauna. Distribution of megafauna in these 'natural' seabed 23 areas seems primarily driven by availability of suitable microhabitats as has been 24 found elsewhere in the Faroe-Shetland Channel (Fautin et al. 2005; Tyler et al. 2005; 25 Jones et al. 2006). The stochastic arrangement of ice rafted larger stones may have 
1 gone some way to structuring the distribution of megabenthos. Most sessile filter

2 feeders lived attached to hard substrata; whereas many echinoderms preferred softer

3 sediments, being more common on gravel and sandy areas of seabed. Many species,

4 particularly Munida sarsii were cryptic, preferring to live under rocks. Strong currents

5 (up to $0.5 \mathrm{~ms}^{-1}$ ) observed at both sites may have had an important effect on the

6 distribution of megafauna as have been observed by Rosenberg (1995) and Flach et al.

7 (1998).

8

9 Comparison of the undisturbed assemblages of Schiehallion and Foinaven

Megafaunal abundance at both sites was variable (from 1,900 to 16,483

12 individuals $\mathrm{ha}^{-1}$ at Foinaven and from 2,178 to 5,626 individuals $\mathrm{ha}^{-1}$ at Schiehallion).

13 Megabenthic abundance has generally been found to decrease with depth (Thurston et

14 al. 1994; Piepenburg et al. 2001); however in the Faroe-Shetland Channel the

15 situation is more complex, with warm Atlantic waters overlaying cold Arctic water

16 (Turrell et al. 1999) with some indication of higher macrofaunal abundances in the

17 deeper cold water compared with the shallower warmer waters (Bett 2001). Results

18 from this study and Jones et al. (2006) suggest this may extend to megafauna. At

19 Foinaven megafaunal abundances were higher than that of Schiehallion. The fauna at

20 Foinaven were at a depth where they must experience wide temperature variations (of

21 around $5^{\circ} \mathrm{C}$ : from -0.5 to $4.5^{\circ} \mathrm{C}$ ), with abundances similar to those found at deeper

22 sites (e.g. Laggan) characterised by Arctic water masses with temperatures between -1

23 and $2^{\circ} \mathrm{C}$ (Jones et al. 2006), however few representatives of the typical Arctic faunas

24 found at greater depths in the Faroe-Shetland Channel extend into the present study

25 sites (Jones et al. 2006). Comparison with the Atlantic fauna of the Rockall Trough, 
1 south of the Wyville-Thomson Ridge, revealed similar assemblages, particularly to

2 those at Schiehallion (Gage 1986) although comparable megafaunal abundance values

3 are not quoted. These comparisons suggest stronger affinities between the shallow

4 Faroe-Shetland Channel and the northeast Atlantic rather than with the Norwegian

$5 \quad$ Basin and other northern waters.

6 Megafaunal species richness values were recalculated as $\mathrm{ES}_{(70)}$ for comparison

7 with other literature (10.8 to 15.1 for Foinaven; 9.3 to 10.7 for Schiehallion). Species

8 richness at Laggan $\left(\mathrm{ES}_{(70)}\right.$ for Laggan between 11.7 and 12.2) was comparable with

9 Foinaven but higher than Schiehallion. This supports the hypothesis that megafaunal

10 richness patterns are similar to those found in macrofauna, with increased diversity at

11 intermediate depths in the Faroe-Shetland Channel (Bett 2001; Narayanaswamy et al.

12 2005). Richness in this study was high in comparison with the Arctic stations

13 investigated by Starmans and Gutt (2002) although these were within the confidence

14 limits for the more diverse shallow Greenland station (Starmans and Gutt 2002). In

15 comparison with the Atlantic, although direct megafaunal diversity measures are

16 unavailable, from species tables and figures it appears that megafaunal diversity in the

17 two areas was similar, with a similar species complement (Gage 1986; Gage et al.

18 2000).

19 There was a clear difference in megafaunal species composition between

20 Foinaven and Schiehallion; this is likely to be predominantly driven by temperature.

21 The fauna at the Schiehallion and Foinaven sites are in an area of natural transition

22 between those organisms more typical of the Atlantic in the warmer shallower waters

23 of the Faroe-Shetland Channel, and those more typical of the Arctic deep Norwegian

24 Sea (Bett 2001). The boundary between warm and cold waters in the Faroe-Shetland

25 Channel oscillates between 400-600 m (Turrell et al. 1999). The fauna of Schiehallion 
1 therefore predominantly live in comparatively warm Atlantic waters. The fauna of

2 Foinaven on the other hand is subject to extreme changes in temperature over very

3 short time scales. The fauna at Laggan, living in constantly cold temperatures, was

4 different again from Foinaven, with only 5 taxa common to both areas (Jones et al.

5 2006). Hydrographic regimes are important in structuring benthic communities (Gage

6 et al. 1995), and environmental temperature is a major contributing factor governing

7 the range of species found in marine communities (Gage and Tyler 1991) particularly

8 in the Faroe-Shetland Channel (Bett 2001; Narayanaswamy et al. 2005). It is also

9 likely that differences in specific taxa may be related to bathymetric gradients in

10 faunal distribution (Gage and Tyler 1982; Rex et al. 1997).

11 This study represents an important step forward in quantifying the effects of

12 anthropogenic disturbance across a number of sites in deep waters, being especially

13 relevant in the context of increasing hydrocarbon drilling at deep-water sites. The use

14 of ROVs for monitoring has been shown to be highly effective in studies of this

15 nature, which, as this technology is routinely used in these developments, may

16 increase industry and science collaboration initiatives in monitoring disturbance and

17 the subsequent recovery of benthic assemblages. Disturbance was shown to have

18 important effects on benthic assemblages particularly through smothering and

19 resultant habitat changes. These changes were difficult to predict, based on individual

20 species ecology but the study of assemblage parameters such as abundance, diversity

21 and faunal distribution reveals the ecosystem level effects of disturbance. This work

22 also provides the foundation for future studies monitoring faunal recovery in these

23 areas. It also helps to identify targets for future directed in situ ROV experimental

24 studies of individual species responses to anthropogenic disturbance. 


\section{ACKNOWLEDGEMENTS}

2

3 The authors wish to acknowledge Transocean Inc. and the crew of the drilling rigs

4 Transocean Leader and Paul B Loyd Junior, Subsea 7 and their ROV teams and the

5 field operator BP (DBU) for supporting this project. This project was carried out as

6 part of the SERPENT Project and DIEPS (Deepwater Industry, Environment, Policy

7 and Science). D. Jones was funded by NERC studentship NER/S/A/2002/10397 and

8 DIEPS grant NE/C508518/1. This work complies with the current laws of the United

9 Kingdom. 


\section{REFERENCES}

3

4 Airoldi L (2003) The effects of sedimentation on rocky coast assemblages.

Aurora (2004) Schiehallion Environmental Statement. Aurora Environmental Ltd, Orkney, UK

Bett BJ (2001) UK Atlantic Margin Environmental Survey: introduction and overview of bathyal benthic ecology. Continental Shelf Research 21: 917-956

Oceanography and Marine Biology 41: 161-236

Bluhm H (2001) Re-establishment of an abyssal megabenthic community after experimental physical disturbance of the seafloor. Deep-Sea Research Part II: Topical Studies in Oceanography 48: 3841-3868

Brey T (1999) Growth performance and mortality in aquatic macrobenthic invertebrates. Advances in Marine Biology 35: 153-223

Clarke KR, Warwick RM (2001) Changes in marine communities: An approach to statistical analysis and interpretation. Plymouth Marine Laboratory, U.K.

Connell JH (1978) Diversity in tropical rain forests and coral reefs. Science 199: $1302-1310$

Davies JM, Bedborough DR, Blackman RAA, Addy JM, Appelbee JF, Grogan WC, Parker JC, Whitehead A (1989) Environmental effects of oil-based mud drilling in the North Sea. In: Englehardt FR, Ray JP, Gillam AH (eds) Drilling wastes. Elsevier Applied Science, London

Dernie KM, Kaiser MJ, Richardson EA, Warwick RM (2003) Recovery of soft sediment communities and habitats following physical disturbance. Journal of Experimental Marine Biology and Ecology 285-286: 415-434 
1 Fautin DG, Daly M, Cappola V (2005) Sea anemones (Cnidaria: Actiniaria) of the

Faroe Islands: A preliminary list and biogeographic context. Annales Societatis Scientiarum Faroensis Supplementum XXXXI. BIOFAR Proceedings 2005, BIOFAR symposium, Torshavn 4-26 April 2003: 77-87

Flach E, Lavaleye M, de Stigter H, Thomsen L (1998) Feeding types of the benthic community and particle transport across the slope of the NW European Continental Margin (Goban Spur). Progress in Oceanography 42: 209-231

Gage JD (1986) The benthic fauna of the Rockall Trough: Regional distribution and bathymetric zonation. Proceedings of the Royal Society of Edinburgh 88: 159174

Gage JD, Lamont PA, Kroeger K, Harvey R (2000) Desktop study of tranches 19-22 Section 2.2, Atlantic Frontier Environmental Network CD ROM. Atlantic Frontier Environmental Network (AFEN)

Gage JD, Lamont PA, Tyler PA (1995) Deep-sea macrobenthic communities at contrasting sites off Portugal. Preliminary results: 1 . Introduction and diversity comparisons. Internationale Revue der gesamten Hydrobiologie 80: 235-250

Gage JD, Tyler PA (1982) Depth-related gradients in size structure and the bathymetric zonation of deep-sea brittle stars. Marine Biology 71: 299-308

Gage JD, Tyler PA (1991) Deep Sea Biology. Cambridge University Press, Cambridge

Gray JS, Clarke AJ, Warwick RM, Hobbs G (1990) Detection of initial effects of pollution on marine benthos: an example from the Ekofisk and Eldfisk oilfields, North Sea. Marine Ecology Progress Series 66: 285-299

Hudson IR, Wigham BD, Tyler PA (2004) The feeding behaviour of a deep-sea holothurian, Stichopus tremulus (Gunnerus) based on in situ observations and 
experiments using a Remotely Operated Vehicle. Journal of Experimental Marine Biology and Ecology 301: 75-91

Jones DOB, Hudson IR, Bett BJ (2006) Effects of physical disturbance on the coldwater megafaunal communities of the Faroe-Shetland Channel. Marine Ecology Progress Series 319: 43-54

Kaiser MJ (1998) Significance of Bottom-Fishing Disturbance. Conservation Biology 12: $1230-1235$

Kingston PF (1992) Impact of offshore oil production installations on the benthos of the North Sea. ICES Journal of Marine Science 49

Levin LA, Etter RJ, Rex MA, Gooday AJ, Smith CR, Pineda J, Stuart CT, Hessler RR, Pawson D (2001) Environmental influences on regional deep-sea species diversity. Annual Review of Ecology and Systematics 32: 51-93

Magurran AE (2003) Measuring Biological Diversity. Blackwell Science, Oxford

Manly BFJ (1998) Randomization, bootstrap and Monte Carlo methods in biology. Chapman and Hall, London

Masson DG (2001) Sedimentary processes shaping the eastern slope of the FaroeShetland Channel. Continental Shelf Research 21: 825-857

Miller RG (1981) Simultaneous statistical inference. McGraw-Hill, New York

Narayanaswamy BE, Bett BJ, Gage JD (2005) Ecology of bathyal polychaete fauna at an Arctic-Atlantic boundary (Faroe-Shetland Channel, North-east Atlantic). Marine Biology Research 1: 20-32

Olsgard F, Gray JS (1995) A Comprehensive Analysis of the Effects of Offshore Oil and Gas Exploration and Production on the Benthic Communities of the Norwegian Continental-Shelf. Marine Ecology Progress Series 122: 277-306 
1 Piepenburg D, Brandt A, von Juterzenka K, Mayer M, Schnack K, Seiler D, Witte U,

2

3

4 Spindler M (2001) Patterns and determinants of the distribution and structure of benthic faunal assemblages in the northern north Atlantic. In: Schafer P, Ritzrau M, Schluter M, Thiede J (eds) The Northern North Atlantic: A changing environment. Springer, Berlin, pp 179-198

Piepenburg D, Schmid MK (1997) A photographic survey of the epibenthic megafauna of the Arctic Laptev Sea shelf: distribution, abundance and estimates of biomass and organic carbon demand. Marine Ecology Progress Series 147: 63-75

Radziejewska T, Stoyanova V (2000) Abyssal epibenthic megafauna of the ClarionClipperton area (NE Pacific): changes in time and space versus anthropogenic environmental disturbance. Oceanological Studies. Gdansk 29: 83-101

Raghukumar C, Loca Bharathi PA, Ansari ZA, Nair S, Ingole BS, Sheelu G, Mohandass C, Nath BN, Rodrigues N (2001) Bacterial standing stock, meiofauna and sediment nutrient characteristics: indicators of benthic disturbance in the Central Indian Basin. Deep-Sea Research Part II: Topical Studies in Oceanography 48: 3381-3399

Ramsay K, Kaiser MJ, Hughes RN (1998) Responses of benthic scavengers to fishing disturbance by towed gears in different habitats. Journal of Experimental Marine Biology and Ecology 224: 73-89

Rex MA, Etter RJ, Stuart CT (1997) Large-scale patterns of species diversity in the deep-sea benthos. Cambridge University Press, New York

Rogers CS (1990) Reponses of coral reefs and reef organisms to sedimentation. Marine Ecology Progress Series 62: 185-202 
1 Rosenberg R (1995) Benthic marine fauna structured by hydrodynamic processes and food availability. Netherlands Journal of Sea Research 34: 303-317

Sharma R, Nath BN, Parthiban G, Sankar SJ (2001) Sediment redistribution during simulated benthic disturbance and its implications on deep seabed mining. Deep-Sea Research Part II: Topical Studies in Oceanography 48: 3363-3380

Snelgrove PVR, Grassle JP, Grassle JF, Petrecca RF, Ma HG (1999) In situ habitat selection by settling larvae of marine soft- sediment invertebrates. Limnology and Oceanography 44: 1341-1347

Sousa WP (1984) The role of disturbance in natural communities. Annual Review of Ecology and Systematics 15: 353-391

Starmans A, Gutt J (2002) Mega-epibenthic diversity: a polar comparison. Marine Ecology Progress Series 225: 45-52

Stronkhorst J, Ariese F, Van Hattum B, Postma JF, De Kluijver M, Besten PJD, Bergman MJN, Daan R, Murk AJ, Vethaak AD (2003) Environmental impact and recovery at two dumping sites for dredged material in the North Sea. Environmental Pollution 124: 17-31

Thrush SF, Hewitt JE, Cummings VJ, Dayton PK (1995) The impact of scallop dredging on marine benthic communities: what can be predicted from the results of experiments? Marine Ecology Progress Series 129: 141-150

Thurston MH, Bett BJ, Rice AL, Jackson PAB (1994) Variations in the invertebrate abyssal megafauna in the North Atlantic Ocean. Deep-Sea Research Part I: Oceanographic Research Papers 41: 1321-1348

Tuck I, Hall SJ, Robertson M, Armstrong E, Basford D (1998) Effects of physical trawling disturbance in a previously unfished sheltered Scottish sea loch. Marine Ecology Progress Series 162: 227-242 
1 Turrell WR, Slesser G, Adams RD, Payne R, Gillibrand PA (1999) Decadal variability in the composition of Faroe Shetland Channel bottom water. DeepSea Research Part I: Oceanographic Research Papers 46: 1-25

4 Tyler PA, Emson RH, Sumida PYG, Howell KL (2005) Ophiuroid distribution at sublittoral and bathyal depths round the Faroe Islands, NE Atlantic Ocean. Annales Societatis Scientiarum Faroensis Supplementum XXXXI. BIOFAR Proceedings 2005, BIOFAR symposium, Torshavn 4-26 April 2003: 175-194

8 


\section{FIGURES}

3 Figure 1: Bathymetry of the West of Shetland area, north of Scotland, UK, showing

4 the position of the sampling sites at the Schiehallion and Foinaven fields (cross

5 symbol). Laggan site also identified (star symbol) for comparison with Jones et al.

6 (2006).

7

8 Figure 2: ROV video transects conducted at Foinaven and Schiehallion fields, West of

9 Shetland, showing the extent of the visible drill spoil, subsea structures and $50 \mathrm{~m}$ 10 zones radiating from sources of disturbance.

12 Figure 3: Abundances of motile and sessile megafauna in Foinaven (A) and 13 Schiehallion (B) fields, West of Shetland. Error bars represent 95\% confidence 14 intervals derived from bootstrapping.

15

16 Figure 4: Alpha species diversity from ROV video survey of megabenthos in 17 Foinaven (A) and Schiehallion (B) fields, West of Shetland. Shannon-Wiener Index, $18\left(\mathrm{H}^{\prime} \log\right.$ e), Total number of taxa observed (S), plotted with distance zones from source 19 of disturbance.

20

21 Figure 5: Multidimensional scaling ordination (based on Bray-Curtis similarities 22 computed from root transformed abundances) of megafauna from ROV video footage 23 in 50m zones from drilling disturbance at Foinaven and Schiehallion fields, West of 24 Shetland. 
1 Figure 6: Percentage similarity of ROV megafaunal video transects based on 2 Hierarchical cluster analysis (based on Bray-Curtis similarities of root transformed 3 abundances) of megafauna from ROV video footage in 50m zones radiating from 4 drilling disturbance at Foinaven and Schiehallion fields, West of Shetland. 
1 TABLES

2

3 Table 1: Densities of megafaunal taxa within concentric $50 \mathrm{~m}$ zones around two oil

4 drilling sites, Foinaven and Schiehallion, West of Shetland. Species densities (no ha-1)

5 tabulated by distance from source of disturbance (50 meter distance zones).

6 


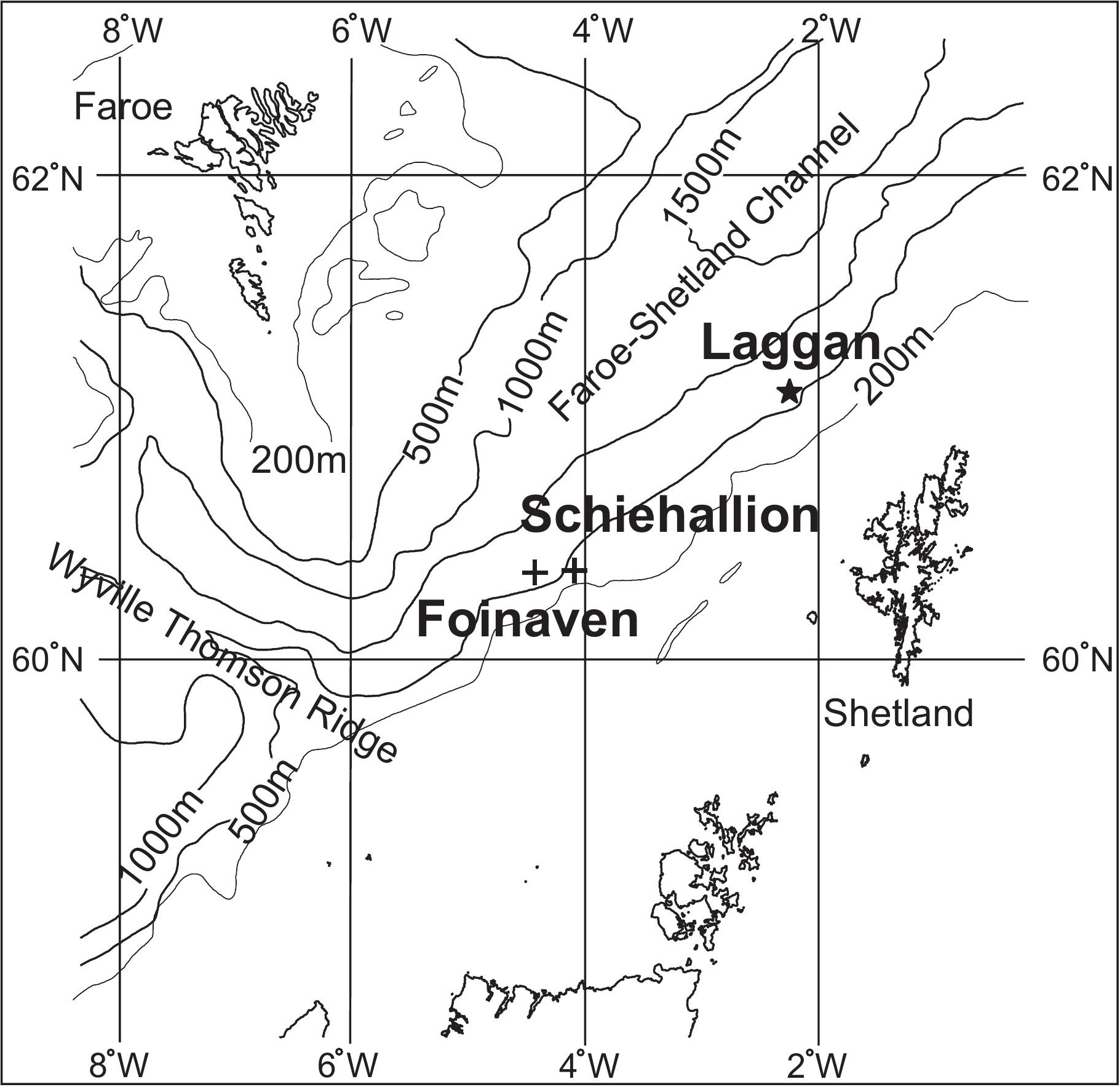




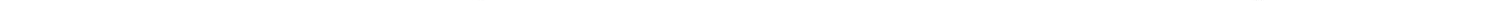


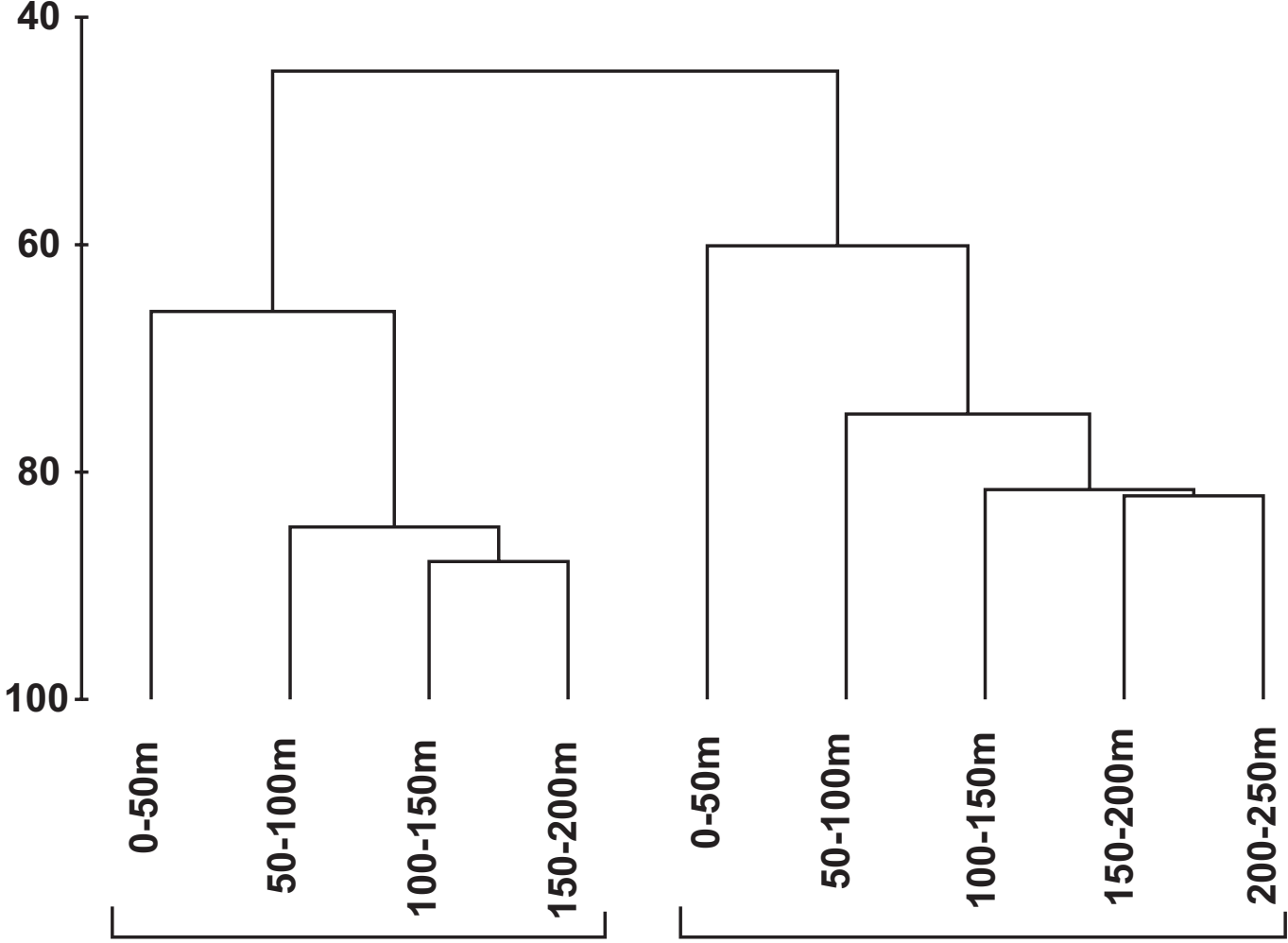

Schiehallion

Foinaven 
Table 1:

\begin{tabular}{|c|c|c|c|c|c|c|c|c|c|c|c|}
\hline \multirow[b]{2}{*}{ Phylum } & \multirow[b]{2}{*}{ Class } & \multirow[b]{2}{*}{ Species } & \multicolumn{5}{|c|}{ Foinaven } & \multicolumn{4}{|c|}{ Schiehallion } \\
\hline & & & $0-50$ & $\begin{array}{l}50- \\
100\end{array}$ & $\begin{array}{l}100- \\
150\end{array}$ & $\begin{array}{l}150- \\
200\end{array}$ & $\begin{array}{l}200- \\
250\end{array}$ & $0-50$ & $\begin{array}{l}50- \\
100\end{array}$ & $\begin{array}{l}100- \\
150\end{array}$ & $\begin{array}{l}150- \\
200\end{array}$ \\
\hline \multirow[t]{10}{*}{ Porifera } & demospongia & Indet. sponge 1 & & & & 12 & & 18 & 44 & 29 & 18 \\
\hline & & Indet. sponge 2 & & 192 & 824 & 3 & 22 & & & & \\
\hline & & Indet. sponge 3 & & & & 6 & & & & & \\
\hline & & Indet. sponge 4 & 12 & 192 & 165 & 24 & 44 & 35 & 117 & 352 & 233 \\
\hline & & Indet. sponge 5 & 169 & 1779 & 1319 & 212 & 4176 & 1611 & 2168 & 255 & 3142 \\
\hline & & $\begin{array}{c}\text { Hymedesmia } \\
\text { paupertas? }\end{array}$ & & 48 & & 12 & 73 & & & 44 & 9 \\
\hline & & $\begin{array}{l}\text { Indet. encrusting } \\
\text { sponge } 1\end{array}$ & & & 22 & 12 & & & & & \\
\hline & & $\begin{array}{l}\text { Indet. encrusting } \\
\text { sponge } 2\end{array}$ & & & 55 & & & & & & \\
\hline & & $\begin{array}{l}\text { Indet. encrusting } \\
\text { sponge } 3\end{array}$ & & 336 & 495 & 24 & 293 & 18 & 13 & 59 & 9 \\
\hline & & $\begin{array}{c}\text { Aplysilla } \\
\text { sulphurea? }\end{array}$ & & 529 & 659 & 91 & 513 & 35 & 117 & 249 & 198 \\
\hline \multirow[t]{2}{*}{ Cnidaria } & actiniaria & Indet. actinarian 1 & & & 55 & & & & & & \\
\hline & & Indet. actinarian 2 & 12 & & & 6 & & & & & \\
\hline Annelida & $\begin{array}{l}\text { polychaeta - } \\
\text { errantia }\end{array}$ & $\begin{array}{l}\text { Indet. errant } \\
\text { polychaete }\end{array}$ & 12 & 96 & 549 & 3 & 73 & & 15 & & \\
\hline \multirow[t]{3}{*}{ Mollusca } & gastropoda & Indet. buccinid & 12 & 48 & 22 & 12 & 513 & & & & \\
\hline & bivalvia & Indet. pectenid & & 48 & 55 & & & & & 15 & 18 \\
\hline & cephalopoda & Sepiola atlantica & & & 55 & & & & & & \\
\hline \multirow[t]{6}{*}{ Arthropoda } & decapoda & Pandalus borealis & 61 & & 165 & & & & & & \\
\hline & & Geryon sp. & & & & & & 18 & 15 & 29 & 72 \\
\hline & & Pagarus sp. & 36 & 192 & 385 & 18 & 147 & & & 15 & \\
\hline & & Cancer pagarus & & & & & & & & & 18 \\
\hline & & Munida sarsii & 666 & 69 & 555 & 65 & 733 & 89 & 791 & 63 & 35 \\
\hline & amphipoda & Siphonocetes sp. & 12 & 144 & 55 & 12 & & & & & \\
\hline \multirow[t]{11}{*}{ Echinodermata } & crinoidea & Indet. comatulid & & & & 12 & 147 & & & & \\
\hline & ophiuroidea & Indet. ophiuroid & 19 & 144 & & 12 & 147 & & & & \\
\hline & asteroidea & $\begin{array}{c}\text { Ceramaster } \\
\text { granularis }\end{array}$ & & 48 & 55 & 6 & 73 & 35 & 44 & 132 & 18 \\
\hline & & Asterias rubens & 12 & & & & & & 29 & 29 & 36 \\
\hline & & Henricia pertusa & & & 55 & 6 & 147 & 53 & 132 & 161 & 18 \\
\hline & & $\begin{array}{c}\text { Porania pulvillus } \\
\text { pulvillus }\end{array}$ & & & 55 & & & 18 & & 15 & \\
\hline & echinoidea & $\begin{array}{c}\text { Indet. } \\
\text { echinothurid }\end{array}$ & 641 & 1634 & 824 & 121 & 1538 & & & & \\
\hline & & Echinus acutus & & 48 & & & 73 & & & & \\
\hline & & Echinus sp. & 12 & 144 & 165 & 48 & 293 & & & & \\
\hline & & Cidaris cidaris & & & & & & 177 & 835 & 1143 & 88 \\
\hline & holothuria & $\begin{array}{c}\text { Stichopus } \\
\text { tremulus }\end{array}$ & 19 & 769 & 385 & 3 & 44 & 71 & 293 & 22 & 233 \\
\hline \multirow[t]{3}{*}{ Chordata } & chondrichthyes & $\begin{array}{l}\text { Chimaera } \\
\text { monstrosa }\end{array}$ & 12 & & & & 73 & & & & \\
\hline & osteichthyes & $\begin{array}{c}\text { Lophius } \\
\text { piscatorius }\end{array}$ & 12 & & & & & & & & \\
\hline & & Paraliparis sp. & & & & & 73 & & & & \\
\hline \multirow[t]{2}{*}{ Total } & & Abundance & 1900 & 12402 & 11868 & 13151 & 16484 & 2178 & 4703 & 5626 & 5477 \\
\hline & & Number of taxa & 16 & 18 & 22 & 22 & 20 & 12 & 13 & 16 & 15 \\
\hline
\end{tabular}

